\title{
Sociological Analysis of Community Participation in Sustainable Water Supply in Rural Areas of Punjab, Pakistan
}

\author{
Muhammad Aasim \\ Department of Sociology, University of Sargodha, Pakistan \\ Dr. Babak Mahmood \\ Assistant professor, Department of Sociology, University of Sargodha, Pakistan \\ Malik Muhammad Sohail \\ Department of Sociology, University of Sargodha, Pakistan
}

\section{Doi:10.5901/mjss.2016.v7n2s1p448}

\section{Abstract}

There are many questions arising about country's ability to ensure adequate water supplies for residents. This study aims to examine the degree of participation of community in supplying the water and further to explore certain sociological factors that may promote or impede the supply of water. In present study collected data was used for developing a causal relationship among the variables. The sample size consists of $n=300$. Two rural water supply schemes were selected from each District. For collection of data cross sectional survey research method was used. Interview schedule was formed as data collection tool to gather information from respondents who were head of house hold. It is found that empowerment of local people in operation and maintenance tasks of development projects enhance ownership of these projects, in terms of sustainability. It was found that lack of interest of line departments, non-fulfillment of promised benefits and lack of sense of ownership in community is the reason of dissatisfaction with the operating system of water services in their village. The findings of the present study clearly warrant the need for increased rural water supply programs and active engagement of people in quality assurance such schemes.

Keywords: Community Participation, Sustainable Water Supply, Rural Areas, Punjab

\section{Background}

There is a growing consensus among scientists that physical shortage of water is a challenge ahead that is likely to be a source of regional and international debates. Recent assessments have shown that water stress could undermine the living conditions of people all over the world (Scheffram \& Battaglini, 2011). Unfortunately, water is seldom considered a public good or a basic human right in many parts of the world. All over the world, especially in developing countries, industrial projects and excessive use of chemicals and fertilizers pollute and contaminate water reservoirs (Clark \& York, 2005). It is reported that currently about 1.2 billion people are affected by water scarcity problem that will turn into 2.7 to 3.5 billion people by 2025 , if effective steps are not taken. In many countries, water scarcity compels the local population to use wastewater for irrigation purposes, but this serves to disperse microbes into the environment. Since untreated wastewater contains human and animal feces and other dangerous chemicals, the crops produced using this water may be contaminated with various pathogens and dangerous substances (Ensink \& Hoek, 2009). United Nation's Millennium Declaration emphasized the significance of water (UN, 2003). It has been reported in 2006 Millennium Report that there are significant achievements for reduction in the number of people without having access to safe drinking water from $30 \%$ to $20 \%$ in 1990 and 2004, respectively. The mostly deprived populations from safe water live in Latin American (15 percent), African (25 percent), and Asian (57 percent) cities (UN-Habitat, 2003). Potential consequences of water scarcity for security, the environment, and human well-being are grave (Brown \& McLeman, 2009).

However, in spite of most reasonable investments in the water sector, the outcome on access to safe water remains frightful at all over the world. Water related diseases are amongst the most common cause of illness and death $70 \%$ diseases are due to polluted water and $40 \%$ deaths are water related (Noll et al., 2000). More than three million world's population's death is due to diseases caused by unsafe water in the developing countries every year. Almost 17 
million people in Pakistan have no access to portable water (Asian Development Bank, 2004).Pakistan's Water at Risk (2009) - A report by World Wide Fund for Nature (WWF) narrates that while Pakistan has significant groundwater resources and surface, rapidly growing population and injudicious water consumption trends in the domestic, industrial and agriculture sectors have placed a much stress on both the quantity and quality of water resources.

Punjab has an adverse face in this sector. According to the official record of the Public Health Engineering Department, Government has completed almost 4000 rural water supply schemes till now in this sector, among them 1600 are abandoned. These non-functional rural eater supply schemes are great in numbers. In 1992 45\% Pakistanis having contact withenhanced drinking water sources. In 2004 the country was at 85\%, but in South Asia still 222 million of its population is without way in to enhanced potable water sources. But in Pakistan there isa big urban rural gap as 92\% of urban population has contact with enhanced drinking water sources as compare to $41 \%$ of its countryside counterpart. This correlates with poverty as in 1999 , poverty in rural areas of Pakistan was at $36.3 \%$, while poverty in urban areas was at 22.6\% (Asian Development Bank 2002).

There are established warnings that groundwater, especially in parts of India, northern China, and Pakistan, is being exhausted at a rate higher that its replenishment (Butler, 2009). Water scarcity is the greatest future menace to the viability of Pakistan as society and state. While this contention may be magnified, one can hardly dispute its underlying premise. Pakistan's water situation is highly unsecure. The availability of water that was about 5,000 cubic meters per capita in the early 1950s has decreased to 1,500 cubic meters per capita today. According to 2008 data from the Food and Agriculture Organization, Pakistan's total water availability per capita ranks dead last in a list of 26 Asian countries and the United States. Pakistan is expected to become water scarce (the designation of a corneal water availability below $1,000 \mathrm{m3}$ per capita) by 2035, though some experts project this may happen as soon as 2020, if not earlier (Lieven \& Hulsman, 2007). The major challenges to Pakistan's water includes agriculturally deficient irrigation (Among the total allocated water resources in Pakistan only 97 percent is utilized to support one of the lowest productivities in the world per unit of water), awful urban sanitation facilities, and disastrous environmental damage Another hindrance is an absence of water laws to describe water rights.

\section{Rural Water Supply}

RWS systems are commonly defined as those water supply systems that operate independently of other formal services (Schouten and Moriarty 2003, p. 10). These systems may be rural or otherwise independent of a municipal supply network or, simply, a RWS may be a water system established where the regional water management agency does not have authority or the ability to extend infrastructure (Swartz and Ralo 2004). Some of the infrastructure features of a RWS system include boreholes, raw water mains, elevated tanks, roof rain-water catch tanks, small diversion dams, and gravity powered pumps (e.g., hydraulic rams). RWS systems are also defined by a type of management and governance, which is often community based and derived from social rules and socially agreed upon modes of operation (Metcalf \& Eddy, 2003).

\section{Methodology}

In present study collected data was used for developing a causal relationship among the variables. The sample size consists of $n=300$. In first stage two division were selected, from central Punjab (Fisalabad, Sargodha). In second stage two Districts from each division were selected. Total four Districts of two Divisions were selected. Sargodha and Khushab from Sargodha division, Faisalabad and Chiniot from Faisalabad Division were selected respectively. Furthermore two rural water supply schemes were selected from each District. 38respondents/household was taken from each rural water supply schemes out of these eight selected schemes of these four Districts.For collection of data cross sectional survey research method was used. The survey research method was used for the collection of data and a team of interviewer was formed headed by researcher to interview the respondents who were head of house hold.

\section{Data Analysis}

Table 1: Distribution of respondents according to their Demographic Characteristics

\begin{tabular}{|l|c|c|l|c|c|}
\hline Age Group & Frequency $(\boldsymbol{f})$ & Percentage & Gender & Frequency $(\boldsymbol{f})$ & Percentage \\
\hline $\mathbf{1 8 - 2 5}$ years & 31 & 10.7 & Male & 273 & 94.1 \\
\hline $\mathbf{2 6 - 3 3}$ years & 40 & 13.8 & Female & 17 & 5.9 \\
\hline
\end{tabular}




\begin{tabular}{|l|c|c|l|c|c|}
\hline $34-41$ years & 71 & 24.5 & & & \\
\hline $42-49$ years & 47 & 16.2 & Water Sources & & \\
\hline 50 and above & 101 & 34.8 & Hand Pump & 9 & 3.1 \\
\hline Marital Status & & & Water Supply Scheme & 277 & 95.5 \\
\hline Single & 44 & 15.2 & Less than 5 Acre & 161 & 55.5 \\
\hline Married & 246 & 84.8 & Less than 25 Acre & 15 & 5.2 \\
\hline Monthly income & & & More than 25 Acre & 7 & 2.4 \\
\hline Up to 3000 & 152 & 52.4 & & & \\
\hline 3001-5000 & 106 & 36.6 & Water Consumption & & \\
\hline Above 5000 & 32 & 11.00 & 10 Gallons & 49 & 16.9 \\
\hline Above 5 & 17 & $14.2 \%$ & 15 Gallons & 68 & 23.4 \\
\hline Size of family & & & 20 Gallons & 91 & 31.4 \\
\hline $1-3$ members & 20 & 6.9 & 25 Gallons & 54 & 18.6 \\
\hline 4-6 members & 141 & 48.6 & More than 25 Gallons & 22 & 7.6 \\
\hline 7-9 members & 102 & 35.2 & & & \\
\hline Above 10 members & 27 & 9.3 & Total & 290 & 100.0 \\
\hline
\end{tabular}

Table 1 presents the descriptive statistics of demographic traits of the respondents. Age is an important factor in any social research. 40 respondents (13.8 percent) were from 26-33 years age group. 71 respondents (24.5 percent) belonged to age bracket of 34-41 years. 101 respondents (34.8 percent) were from age bracket of 50 years and above. Hence, majority of the respondents were from age group of 50 years and above. Another demographic characteristic is Gender of the respondents. 273 respondents (94.1 percent) were male whereas 17 respondents were male (5.9 percent) were female.Nextvariable is marital status of the respondents. 44 respondents (15.2 percent) were single whereas 246 respondents 246 were male (5.9 percent) were married among total number of 290 . Household Income of the respondents was also gauged in this study. A majority of i.e., 152 respondents (52.4 percent) were having Rs. Up to 3000 household income. It was necessary to explore water sourcesof the respondents to study community participation in sustainable water supply schemes. Only 9 respondents (3.1 percent) were having hand pump in their houses while a huge majority of i.e., 277 respondents (95.5 Percent) were using water supply scheme for their water usage.Table 1 also presents the descriptive statistics of Water Consumptionof the respondents. 49 respondents (16.9 percent) were consuming 10 Gallons of water, 68 respondents (23.4 percent) were consuming 15 Gallons of water, landless, 91 respondents (31.4 percent) were consuming 20 Gallons of water, whereas 54 respondents (18.6 percent) were consuming 25 Gallons of water and 22 respondents ( 7.6 percent) were consuming more than 25 Gallons of water in their houses.

Table 2: Distribution of the respondents according to Water Consumption

\begin{tabular}{|l|c|c|c|}
\hline Question & To great extent & To some extent & Not at all \\
\hline water supply sources (Deep well pump, Hand pump, WASA supply) & 254 & 35 & 1 \\
have influenced water usage practices & $87.6 \%$ & $12.1 \%$ & $.1 \%$ \\
\hline \multirow{2}{*}{ water consumption management in household is controlled by women } & 269 & 21 & 0 \\
\hline \multirow{2}{*}{ women excessively use water in performing daily domestic activities } & $93.1 \%$ & $6.9 \%$ & 27 \\
& $90.7 \%$ & $9.3 \%$ & 0 \\
\hline Community Participation Exists in Planning Phase & 99 & 178 & 13 \\
\hline Community Participation Exists in Monitoring Phase & $34.3 \%$ & $61.6 \%$ & $4.1 \%$ \\
\hline Community Participation Exists in Revenue Collection Phase & 95 & 137 & 58 \\
& $32.8 \%$ & $47.2 \%$ & $20 \%$ \\
\hline Community Participation Exists in Maintenance Phase & $29.7 \%$ & 87 & 117 \\
\hline Water Management Committee is Functional in your Village & 139 & 112 & $30.3 \%$ \\
\hline meeting of water management committee is necessary for operation of & 212 & $38.6 \%$ & $13.5 \%$ \\
\hline rural water scheme & $73.1 \%$ & 95 & 7 \\
\hline lack of interest is the reason of nonfunctioning of water management & 137 & $32.8 \%$ & $2.7 \%$ \\
\hline
\end{tabular}




\begin{tabular}{|c|c|c|c|}
\hline committee & 47.25 & $52.4 \%$ & $0.3 \%$ \\
\hline $\begin{array}{l}\text { negligence of line department is the reason of nonfunctioning of water } \\
\text { management committee }\end{array}$ & $\begin{array}{c}46 \\
15.9 \%\end{array}$ & $\begin{array}{c}210 \\
72.4 \%\end{array}$ & $\begin{array}{c}34 \\
11.7 \%\end{array}$ \\
\hline $\begin{array}{l}\text { political pressure is the reason of nonfunctioning of water } \\
\text { management committee }\end{array}$ & $\begin{array}{c}78 \\
26.9 \%\end{array}$ & $\begin{array}{l}203 \\
70 \%\end{array}$ & $\begin{array}{c}9 \\
3.1 \% \\
\end{array}$ \\
\hline $\begin{array}{l}\text { chairman is the responsible for day to day management activities of } \\
\text { water scheme in your village }\end{array}$ & $\begin{array}{c}154 \\
53.1 \%\end{array}$ & $\begin{array}{c}135 \\
46.6 \%\end{array}$ & $\begin{array}{c}1 \\
.3 \%\end{array}$ \\
\hline $\begin{array}{l}\text { executive body is the responsible for day to day management } \\
\text { activities of water scheme in your village }\end{array}$ & $\begin{array}{c}216 \\
74.5 \%\end{array}$ & $\begin{array}{c}74 \\
25.5 \%\end{array}$ & 0 \\
\hline
\end{tabular}

Table 2 presents that a majority of 254 respondents (87.6 Percent) were agreed that supply sources (Deep well pump, Hand pump, WASA supply) have influenced their water usage practices to great extent.There is another dimension to water inequality in terms of its access by gender and exists an intimate relationship of women in developing countries to water (Seyfried, 2011). 269 respondents (93.1 Percent) were agreed to great extent that the water consumption management in the household is controlled by the women. 263 respondents (90.7 Percent) were agreed to great extent that women excessively use water in performing daily domestic activities.99 respondents (34.3 Percent) were agreed that community participation exists in planning phase to great extent while 178 respondents (61.6Percent) were saying community participation exists in planning phase, to some extent.One third i.e., 95 respondents (32.8 Percent) were agreed that community participation exists in monitoring phase to great extent while 137 respondents (47.2 Percent) were saying community participation exists in monitoring phase, to some extent as only 58 respondent (20 Percent) were of view that community participation exists in monitoring phase, not at all.86 respondents (29.7 Percent) were agreed that community participation exists in revenue collection phase to great extent while 87 respondents ( 30 Percent) were saying community participation exists in revenue collection phase.

139 respondents (47.9 Percent) were agreed that community participation exists in maintenance phase to great extent.187 respondents (64.5 Percent) were agreed that Water Management Committee is Functional in their Village, to great extent while 95 respondents (32.8 Percent) were saying that Water Management Committee is Functional in their Village.212 respondents (73.1 Percent) were agreed that meeting of water management committee is necessary for the operation of rural water scheme, to great extent while 77 respondents (26.6 Percent) were saying that meeting of water management committee is necessary for the operation of rural water scheme, to some extent as only one respondent (0.3 Percent) were of view that meeting of water management committee is necessary for the operation of rural water scheme, not at all.

Majority of the respondents 212 respondent (73.1 Percent) were that Water Management Committee is Functional in their Village.178 respondents (61.4 Percent) were agreed that meeting of water management committee is necessary for the operation of rural water scheme, to great extent while 110 respondents (37.9 Percent) were saying that meeting of water management committee is necessary for the operation of rural water scheme, to some extent. A little less than half majority i.e., 137 respondents (47.2 Percent) were agreed that lack of interest is the reason of nonfunctioning of water management committee, to great extent while 152 respondents (52.4 Percent) were saying that lack of interest is the reason of nonfunctioning of water management committee, to some extent.210 respondents (72.4 Percent) were saying that negligence of line department is the reason of nonfunctioning of water management committee, to some extent.78 respondents (26.9 Percent) were agreed that agreed that political pressure is the reason of nonfunctioning of water management committee, to great extent while 203 respondents (70.0 Percent) were saying that political pressure is the reason of nonfunctioning of water management committee, to some extent.216 respondents (74.5 Percent) were agreed that executive body is the responsible for day to day management activities of water scheme in your village, to great extent while 74 respondents (25.5 Percent) were saying that the executive body is the responsible for day to day management activities of water scheme in your village, to some extent.

Table 3: Distribution of the respondents according to their perception about sustainable water supply

\begin{tabular}{|c|c|c|c|}
\hline Question & To great extent & To some extent & Not at all \\
\hline Are you satisfied with operating system of water services in your village & $\begin{array}{c}237 \\
81.7 \%\end{array}$ & $\begin{array}{c}53 \\
18.3 \% \\
\end{array}$ & 0 \\
\hline $\begin{array}{l}\text { none compliance of water management committee is the reason of } \\
\text { dissatisfaction with operating system of water services in your village }\end{array}$ & $\begin{array}{c}280 \\
96.6 \%\end{array}$ & $\begin{array}{c}10 \\
3.4 \% \\
\end{array}$ & 0 \\
\hline $\begin{array}{l}\text { lack of interest of line department is the reason of dissatisfaction with operating } \\
\text { system of water services in your village }\end{array}$ & $\begin{array}{c}266 \\
91.7 \% \\
\end{array}$ & $\begin{array}{c}24 \\
7.3 \% \\
\end{array}$ & 0 \\
\hline
\end{tabular}




\begin{tabular}{|c|c|c|c|}
\hline $\begin{array}{l}\text { non fulfillment of promised benefits is the reason of dissatisfaction with operating } \\
\text { system of water services in your village }\end{array}$ & $\begin{array}{c}241 \\
83.1 \%\end{array}$ & $\begin{array}{c}49 \\
16.7 \%\end{array}$ & 0 \\
\hline $\begin{array}{l}\text { lack of sense of ownership in community is the reason of dissatisfaction with the } \\
\text { operating system of water services in your village }\end{array}$ & $\begin{array}{c}277 \\
95.5 \% \\
\end{array}$ & $\begin{array}{c}13 \\
4.5 \% \\
\end{array}$ & 0 \\
\hline $\begin{array}{l}\text { rural water supply scheme has made your life easier and improved your social } \\
\text { status }\end{array}$ & $\begin{array}{c}184 \\
63.4 \%\end{array}$ & $\begin{array}{c}106 \\
36.4 \%\end{array}$ & 0 \\
\hline rural water supply scheme is cost effective than getting water from other sources & $\begin{array}{c}143 \\
49.3 \% \\
\end{array}$ & $\begin{array}{c}147 \\
50.7 \% \\
\end{array}$ & 0 \\
\hline water supply scheme has played positive role on your health & $\begin{array}{c}17 \\
5.9 \%\end{array}$ & $\begin{array}{c}213 \\
73.4 \%\end{array}$ & $\begin{array}{c}60 \\
20.7 \%\end{array}$ \\
\hline $\begin{array}{l}\text { there is role of women as the major water users in the decision making of water } \\
\text { management committee }\end{array}$ & $\begin{array}{c}38 \\
13.1 \%\end{array}$ & $\begin{array}{l}232 \\
80 \%\end{array}$ & $\begin{array}{c}20 \\
6.9 \%\end{array}$ \\
\hline $\begin{array}{l}\text { women can play a positive role in the decision making of water management } \\
\text { committee }\end{array}$ & $\begin{array}{c}127 \\
43.8 \%\end{array}$ & $\begin{array}{c}151 \\
52.1 \%\end{array}$ & $\begin{array}{c}12 \\
4.1 \%\end{array}$ \\
\hline $\begin{array}{l}\text { there are benefits of water services management under community management } \\
\text { system }\end{array}$ & $\begin{array}{c}187 \\
64.5 \%\end{array}$ & $\begin{array}{c}100 \\
34.5 \%\end{array}$ & $\begin{array}{c}3 \\
1 \% \\
\end{array}$ \\
\hline $\begin{array}{l}\text { local community is informed on the income accrued from water services and } \\
\text { expenditures }\end{array}$ & $\begin{array}{c}196 \\
67.6 \%\end{array}$ & $\begin{array}{c}93 \\
32.1 \% \\
\end{array}$ & $\begin{array}{c}1 \\
.3 \%\end{array}$ \\
\hline $\begin{array}{l}\text { capacity building workshops for the water management committee are arranged } \\
\text { by line department }\end{array}$ & $\begin{array}{c}186 \\
64.1 \% \\
\end{array}$ & $\begin{array}{c}104 \\
35.9 \% \\
\end{array}$ & 0 \\
\hline $\begin{array}{l}\text { project can be sustain for long period of time by the capacity building of water } \\
\text { management committee }\end{array}$ & $\begin{array}{c}115 \\
39.7 \% \\
\end{array}$ & $\begin{array}{c}175 \\
60.3 \% \\
\end{array}$ & 0 \\
\hline
\end{tabular}

Table 3 present that 237 respondents (81.7 Percent) were agreed that they were satisfied with operating system of water services in their village, to great extent while 53 respondents (18.3 Percent) were saying that they were satisfied with operating system of water services in their village, to some extent.280 respondents ( 96.6 Percent) were agreed that none compliance of water management committee is the reason of dissatisfaction with operating system of water services in their village, to great extent while 10 respondents (3.4 Percent) were saying that none compliance of water management committee is the reason of dissatisfaction with operating system of water services in their village, to some extent.266 respondents (91.7 Percent) were agreed that lack of interest of line department is the reason of dissatisfaction with operating system of water services in your village, to great extent while 24 respondents ( 7.3 Percent) were saying that lack of interest of line department is the reason of dissatisfaction with operating system of water services in your village, to some extent.241 respondents (83.1 Percent) were agreed that non fulfillment of promised benefits is the reason of dissatisfaction with operating system of water services in their village, to great extent while 49 respondents (16.7 Percent) were saying that non fulfillment of promised benefits is the reason of dissatisfaction with operating system of water services in their village, to some extent.277 respondents (78.3 Percent) were agreed that lack of sense of ownership in community is the reason of dissatisfaction with the operating system of water services in their village, to great extent while 63 respondents (21.7 Percent) were saying that lack of sense of ownership in community is the reason of dissatisfaction with the operating system of water services in their village, to some extent.184 respondents (63.4 Percent) were agreed that rural water supply scheme has made your life easier and improved your social status, to great extent while 106 respondents (36.6 Percent) were saying that rural water supply scheme has made your life easier and improved your social status, to some extent.143 respondents (49.3 Percent) were agreed that rural water supply scheme is cost effective than getting water from other sources, to great extent while 147 respondents (50.7 Percent) were saying rural water supply scheme is cost effective than getting water from other sources, to some extent.17 respondents (5.9 Percent) were agreed that water supply scheme has played positive role on their health, to great extent while 213 respondents (73.4 Percent) were saying that water supply scheme has played positive role on their health, to some extent as 60 respondent (20.7 Percent) were of view that the water supply scheme has played positive role on their health.38 respondents (13.1 Percent) were agreed that there is role of women as the major water users in the decision making of water management committee, to great extent while 232 respondents ( 80.0 Percent) were saying that there is role of women as the major water users in the decision making of water management committee, to some extent as 20 respondent (6.9 Percent) were of view that the role of women as the major water users in the decision making of water management committee.127 respondents (43.8 Percent) were agreed that women can play a positive role in the decision making of water management committee, to great extent while 151 respondents (52.1 Percent) were saying that women can play a positive role in the decision making of water management committee, to some extent as 12 respondent (4.1 Percent) were of view that women can play a positive role in the decision making of water management committee.187 respondent (64.5 Percent) were there are benefits of water services management under community management system.186 respondents (64.1 Percent) were agreed that capacity building workshops for the water management 
committee are arranged by line department, to great extent while 104 respondents (35.9 Percent) were saying that capacity building workshops for the water management committee are arranged by line department, to some extent.115 respondents (39.7 Percent) were agreed that the project can be sustain for long period of time by the capacity building of water management committee, to great extent while 175 respondents (60.3 Percent) were saying that the project can be sustain for long period of time by the capacity building of water management committee, to some extent.

\section{Bi-Variate Analysis: Testing of Hypothesis}

Multiple Linear Regression Analysis

Coefficients $^{\mathrm{a}}$

\begin{tabular}{|l|c|c|c|c|c|}
\hline \multirow{2}{*}{ Model } & \multicolumn{2}{|c|}{ Unstandardized Coefficients } & Standardized Coefficients & \multirow{2}{*}{$\mathrm{t}$} & Sig. \\
\cline { 2 - 5 } & $\mathrm{B}$ & Std. Error & Beta & & \\
\hline (Constant) & .790 & .144 & & 5.494 & .000 \\
Need assessment & .041 & .046 & .056 & .900 & .369 \\
Monitoring & -.055 & .039 & -.102 & -1.414 & .158 \\
Cost sharing & .010 & .033 & .022 & .310 & .756 \\
Promised benefits & -.043 & .034 & -.077 & -1.260 & .209 \\
Sense of ownership & -.004 & .060 & -.004 & -.062 & .951 \\
Community Participation & .062 & .022 & .180 & 2.853 & .005 \\
Decision making & .044 & .032 & .089 & 1.354 & .177 \\
\hline
\end{tabular}

a. Dependent Variable: Sustainability

\begin{tabular}{ll}
\cline { 2 - 2 } Note: ${ }^{*} p<0.000$ & $\begin{array}{l}\text { Adjusted } R^{2}=0.033 \\
\text { Test of the full model: } F=10.721, p=0.000\end{array}$ \\
\cline { 2 - 2 } &
\end{tabular}

In the current regression, community participation was the independent variable and sustainability was the dependent variable. The purpose was to see if the community participation had any effect on sustainability. The results showed $\mathrm{R}^{2}=0.036$ thus showing that approximately $3.6 \%$ of the variance in sustainability listed under the community participation. The overall model proved significant in that $R=0.190, F=10.721, p=0.001$ and the relationship between the two variables was positive leading to the acceptance of hypothesis which stated that there will be a positive relationship between community participation and the sustainability. The value of constant means that if community participation is equal to 0 , then the expected or predicted value for sustainability score is 0.822 . The coefficient values of community participation means that if we increase community participation by one unit, on average, our predicted value for sustainability should reflect an increase of approximately .065 units. The standardized regression coefficient (value for Beta) of 0.190 essentially means that a one standard deviation increase in community participation is associated with $19 \%$ of a standard deviation increase in sustainability.

\section{Conclusions}

The core objective of the present research study was to assess the extent of community participation in rural water supply programs and their sustainability. It may safely be concluded from the findings of the present study that community involvement in planning, execution, operation and maintenance largely contributes towards sustenance of water supply programs in rural area. It may be concluded from the findings of this study that empowerment of local people in operation and maintenance tasks of development projects enhances ownership of these projects, in turn sustainability. It is also concluded that satisfaction with operating system of water services. It was found that lack of interest of line departments, nonfulfillment of promised benefits and lack of sense of ownership in community is the reason of dissatisfaction with the operating system of water services in their village. The findings of the present study clearly warrant the need for increased rural water supply programs and active engagement of people in quality assurance such schemes.

\section{References}

Asian Development Bank (ADB). 2004. Responding to the Priorities of the Poor: A Pacific Strategy for the Asian Development Bank, 2005-2009. Manila: ADB. 
Brown, O., \&McLeman, R. (2009).A recurring anarchy?The emergence of climate change as a threat to international peace and security.Conflict, Security and Development 9(3), 290-304.

Butler, C. D. (2009). Food security in Asia Pacific: climate change, phosphorus, ozone and other environmental challenges. Asia Pacific Journal of Chemical Nutrition 18(4), 590-597.

Clark, B., \& York, R. (2005). Climate metabolism: global capitalism, climate change, and the biosphere rift. Theory and Society, 34, 391427.

Ensink, J.H., Hoek, W. (2009). Implementation of the WHO guidelines for the safe use of wastewater in Pakistan: balancing risks and benefits. Journal of Water and Health, 7(3), 464-68.

Lieven, A., \&Hulsman, J. (2007). Ethical realism: a vision for America's role in the world. New York, Vintage Books.

Metcalf W, Eddy C (2003). Wastewater Engineering. 4th. McGraw-Hill Inc, New York. pp. 377-380.

Noll, R G et al (2000) 'Reforming urban water systems in developing countries', Discussion Paper No 99-32.Stanford Institute for Economic Policy Research, Stanford University.

Scheffran, J., Battaglini, A. (2011). Climate and conflicts: The security risks of global warming. Regional Environmental Change, 11, S27S39.

Seyfried, L. (2011). When it comes to water, we are all equal: Establishing the relationship between women and water (Master thesis). George Washington University, USA.

Swartz CD, Ralo T (2004). Guidelines for planning and design of small water treatment plants for rural communities with specific emphasis on sustainability and community involvement and participation, Silowa Printers, SA. pp. 8.3-8.6.

UN-Habitat (2003) Water and Sanitation in the World's Cities: Local Action for Global Goals. UN.

World Bank, 1990.Bolivia - Social Investment Fund Project.Staff Appraisal Report.Country Department III.Latin America and the Caribbean Region. The World Bank. Washington, D.C. March 26. 